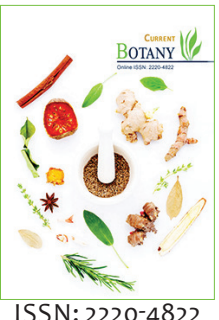

ISSN: $2220-4822$

\title{
GC-MS and FTIR analysis of methanolic leaf extract of Rhynchosia minima (L.) DC.
}

\author{
Vilas T. Patil*, Varsha D. Jadhav \\ Department of Botany, Shivaji University, Kolhapur -416004, Maharashtra, India
}

Received: August 17, 2020 Revised: December 12, 2020 Accepted: December 20, 2020 Published: December 24, 2020

\section{*Corresponding Author:}

Vilas T. Patil

Email: patilvilas725@gmail.com KEYWORDS: GC-MS, FTIR, Methanolic extract, Rhynchosia minima, Fabaceae

\begin{abstract}
ABSTARCT
The current analysis was carried out to determine the chemical components in the leaves of R.minima (L.) DC. The GC-MS analysis of methanolic leaves extract of R. Minima indicated the presence of 19 compounds. The prevailing compounds of R.minima leaves were lPentadecene (14.31), alpha. Bisabolol (10.39\%), lHeptadecene (9.78\%), Cyclohexene,4 (1,5dimethyll, 4hexadienyl (7.06\%), 3Hexadecene (Z) (8.10\%), Caryophyllene (6.58\%), Neophytadiene (5.16\%), Humulene (1.91\%), Naphthalene,1,2,3,5,6,8 a-hexahydro-4,7-dimethyl (3.72\%), Hexadecanoic acid, methyl ester (2.09\%), Pentadecanone (3.13\%), 8-Octadecanone (4.02\%),1-Nonadecene (4.16\%), Spiro[4.5] dec-6-en-8-one,1,7-dimethyl-4-(1-methylethyl (2.97\%), Neophytadiene (2.24\%),(E)-. beta.-Famesene (1.92\%), Cyclohexene,4-[(1E)-1,5-dimethyl-1,4-hexadien (1.80\%), Cyclohexane,octyl (1.45\%), beta Bisabolene (9.21\%). These compounds have antibacterial, antifungal, antioxidant, hemolytic, insecticidal, and lubricant activity. Fourier Transform Infra-Red Spectroscopy (FTIR) leaf anlysis of R.minima shows lipid, protein, phosphate ion, carboxylic acid, hydroxy compound, aliphatic bromo compounds. The present study revealed that $R$. minima leaves represent various types of bioactive compounds. 1-Heptadecene with antibiotic activity, 8-Octadecanone shows antimicrobial activity and hexadecanoic acid, nematicide, antibiotic, antioxidant, hypocholesterolemic production of methyl ester.
\end{abstract}

\section{INTRODUCTION}

The genus Rhynchosia (Fabaceae) belongs to the family Fabaceae (Leguminosae), the subfamily Papilionoideae, the tribe Phaseoleae, the subtribe Cajaninae. The genus is described in India by 25 species, as well as one variety and one subspecies, 7 of which are endemic to India. In India, there is a great diversity of the species of Rhynchosia, about $60 \%$, found in the Eastern Ghat [1].

With its various edible berries, and also great value in the indigenous medicine system, the family fabaceae has an economic significance. Many of the wild edible plant have both therapeutic and dietary function. Wild edible plant plays a significant role in human life, supplying nutrients, fibres, vitamins, essential fatty acids and improving dietary taste and colour. R. minima (L.) DC. Commonly referred to as Turvel is an annual twinning or trailing spread throughout India, Sri Lanka, and the United States [2]. The seeds are weaker and poisonous and the extract of seeds shows strong agglutinating activity on human RBC [3]. The medicine leaves of this plant are used as abortifacient in the folk tradition method. Decoction prepared from leaves is used as an abortifacient by triabals in the North Maharastra region [4]. The Sikkim tribals use plant leaves in the treatment of wounds, helmintic infection and abortion [5]. In the Saurashtra region of Gujarat, the aborigines use the leaves to treat asthama and piles [6]. Plant phytochemical experiments revealed the existence of ergoster, stigmasterol, lupeol, and steroidal glycoside [7]. The Leaves of R. Minima have significant anthelmintic activity [4]. R. Minima leafs essential therapeutic qualities such as contamination with helminths, cuts, asthma, piles and abortive substances [8]. In the case of gold nanoparticles R. minima mediated synthesis, the alkyne group, acyl halide, secondary amine in alkaloids and alkyl halides such as iodine and bromine compounds may be involved in the reduction of gold chloride into gold nanoparticles, these compounds may also serve as reducing and capping agents [9]. Preliminary phytochemical screening of the R.minima aqueous leaf extract indicated the presence of alkaloids, flavonoids, tannins, terpenoids and glycosides [4]. Medicinal plants have historically been an integral part of human life since ancient days. Because of their therapeutic selectivity, minute of side effects, inexpensive source and function as lead molecules for the development of new drugs, natural compounds are currently

Copyright: (C) The authors. This article is open access and licensed under the terms of the Creative Commons Attribution License (http://creativecommons.org/licenses/by/4.0/) which permits unrestricted, use, distribution and reproduction in any medium, or format for any purpose, even commercially provided the work is properly cited. Attribution — You must give appropriate credit, provide a link to the license, and indicate if changes were made. 
the main source for the modern drug discovery. Rhynchosia species (Fabaceae) grow widely in the world's tropical and subtropical areas. In herbal medicine, a few plants of this genus have been used to treat various conditions such as antibacterial, antidiabetic, abortive, wound healing, hepatoprotective, boil cure, rheumatic pain and skin infections [10]. Medicinal plants are a worthy source of biologically active compounds for the production over the past centuries of new therapeutic drug candidates [11-13]. Also today, plant species are commonly used by people in many countries as a cure for the treatment of different forms of diseases such as infectious, cardiovascular, diabetic, intestinal, renal, mental-nervous, dietary, respiratory, reproductive, neurological, skin infections and many wounds [14]. Therefore, the plants provide a valuable source of natural compounds and played a major role with scientifically enhanced effectiveness in the new drug development as well as less side effects [15]. Therefore, in terms of biological activity and drug discovery many researchers based their research attention on medicinal plants.

\section{MATERIALS AND METHODS}

\section{Collection of Plant Material and Preparation of Methanol Extract}

The plant materials of R.minima were collected from Kondi in Solapur District, Maharashtra. The identification of plant material was carrird out by using flora of Kolhapur District [13]. The leaves were air dried at lab condition to avoid contamination and made fine powder by using mechanical grinder. Then the powder was used for extraction using the solvent methanol. The obtained extracts were filtered by using Whatman No.l filter paper, concentrated by using an evaporator at $40{ }^{\circ} \mathrm{C}$ and residual extracts were stored in the refrigerator at $4{ }^{\circ} \mathrm{C}$ in small and sterile amber colour glass bottles. This solution was further used for GCMS analysis. Fine powder of leaves of R. Minima was used to FTIR analysis.

The GC-MS analysis was done using GCMS-TQ8050- Shimadzu (Japan). It has equipped with SH-Rxi-5 sil MS fused silica capillary column $(0.25 \mathrm{~mm}$ diameter and $0.25 \mathrm{~mm}$ thickness $)$. Injection mode- split, Flow control mode - Pressure, Pressure$75.2 \mathrm{kPa}$, linear velocity- $41.4 \mathrm{~cm} / \mathrm{sec}$, Purge flow- $3.0 \mathrm{ml} / \mathrm{min}$ and Spilt ratio-(1.0). Helium gas (99.9\%) was used as a carrier gas at constant flow rate. Identification of components is read on mass spectrum of GC-MS by using National institute of standard and techniques NIST-08 LIB and WILEY-O8 L.

\section{RESULTS AND DISCUSSION}

The GCMS analysis of leaves of R.minima showed Nienteen componds (Table 1). The major phytochemical components were:1-Pentadecene(14.31\%,) alpha.-Bisabolol (10.39\%), 1-Heptadecene (9.78\%), Cyclohexene,4-(1,5-dimethyl-1,4hexadienyl (7.06\%), 3-Hexadecene,(Z)-(8.10\%), Caryophyllene $(6.58 \%)$, Neophytadiene (5.16\%), Humulene (1.91\%), Naphthalene, 1,2,3,5,6,8 a-hexahydro-4,7-dimethyl (3.72\%), Hexadecanoic acid, methyl ester (2.09\%), Pentadecanone $(3.13 \%), 8$-Octadecanone $(4.02 \%), 1-N o n a d e c e n e ~(4.16 \%)$ Spiro[4.5] dec-6-en-8-one,1,7-dimethyl-4-(1-methylethyl (2.97\%), Neophytadiene (2.24\%),(E)-.beta.-Famesene (1.92\%), Cyclohexene,4-[(1E)-1,5-dimethyl-1,4-hexadien (1.80\%), Cyclohexane,octyl (1.45\%), beta-Bisabolene (9.21\%) (Figure 1). Compounds l-Heptadecene and 8-Octadecanone with antibiotic and antimicrobial activity



Figure 1: GC-MS chromatogram of methanolic extract of leaves of R.minima 


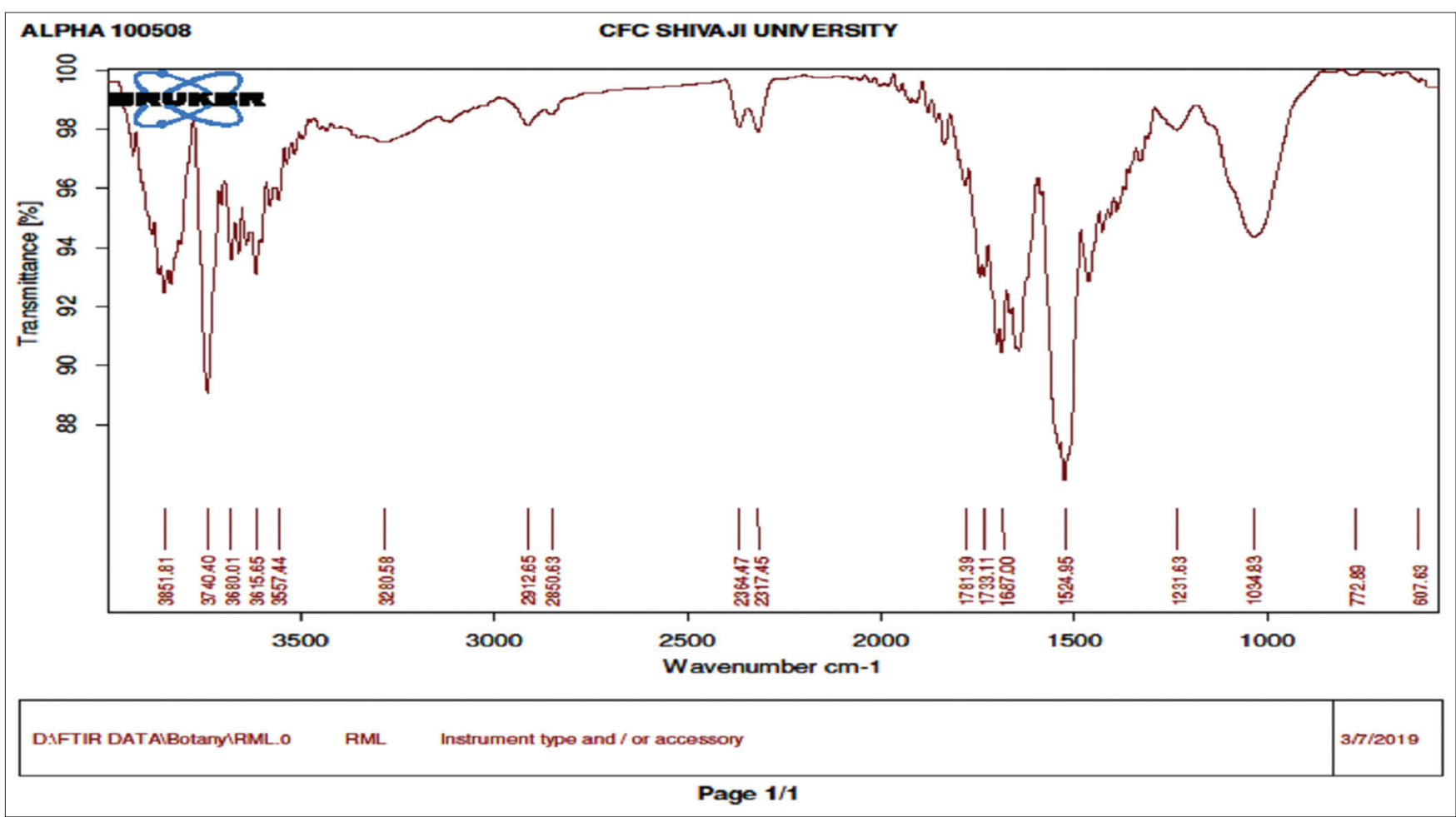

Figure 2: FTIR chromatogram of methanolic extract of Leaves of $R$. minima

Table 1: GC-MS analysis revealed the presence of bioactive compounds in the leaves of methanolic extract of R.minima

\begin{tabular}{|c|c|c|c|c|c|}
\hline Sr No. & Name of compound & Retention time & $\%$ Peak area & Mol. formula & Mol. weight \\
\hline 1 & 3-Hexadecene, (Z)- & 21.300 & 8.10 & $\mathrm{C} 16 \mathrm{H} 32$ & 224 \\
\hline 2 & Caryophyllene & 22.096 & 6.58 & $\mathrm{C} 15 \mathrm{H} 24$ & 204 \\
\hline 3 & Cyclohexane, octyl- & 22.770 & 1.45 & $\mathrm{C} 14 \mathrm{H} 28$ & 196 \\
\hline 4 & E)-.beta.-Famesene & 22.866 & 1.92 & $\mathrm{C} 15 \mathrm{H} 24$ & 204 \\
\hline 5 & Humulene & 23.013 & 1.91 & $\mathrm{C} 15 \mathrm{H} 24$ & 204 \\
\hline 6 & Cyclohexene, 4-(1,5-dimethyl-1,4-hexadienyl & 24.083 & 7.06 & $\mathrm{C} 15 \mathrm{H} 24$ & 204 \\
\hline 7 & .beta.-Bisabolene & 24.270 & 9.21 & $\mathrm{C} 15 \mathrm{H} 24$ & 204 \\
\hline 8 & Naphthalene, 1,2,3,5,6,8a-hexahydro-4,7-dimethyl1-(1-methylethyl)-, (1S-cis) & 24.551 & 3.72 & $\mathrm{C} 15 \mathrm{H} 24$ & 204 \\
\hline 9 & Cyclohexene, 4-[(]E)-1,5-dimethyl-1,4-hexadien & 25.052 & 1.80 & $\mathrm{C} 15 \mathrm{H} 24$ & 204 \\
\hline 10 & 1-Pentadecene & 26.256 & 14.31 & $\mathrm{C} 15 \mathrm{H} 30$ & 210 \\
\hline 11 & 8-Pentadecanon & 28.090 & 3.13 & $\mathrm{C} 15 \mathrm{H} 300$ & 226 \\
\hline 12 & .alpha.-Bisabolo & 28.506 & 10.39 & $\mathrm{C} 15 \mathrm{H} 260$ & 222 \\
\hline 13 & Spiro[4.5]dec-6-en-8-one, 1,7-dimethyl-4-(1-methylethyl & 28.644 & 2.97 & $\mathrm{C} 15 \mathrm{H} 240$ & 220 \\
\hline 14 & 1-Heptadecene & 30.711 & 9.78 & $\mathrm{C} 17 \mathrm{H} 34$ & 238 \\
\hline 15 & Neophytadiene & 31.612 & 5.16 & $\mathrm{C} 2 \mathrm{OH} 38$ & 278 \\
\hline 16 & 8-Octadecanone & 32.394 & 4.02 & $\mathrm{C} 18 \mathrm{H} 360$ & 268 \\
\hline 17 & Hexadecanoic acid, methyl ester & 33.438 & 2.09 & $\mathrm{C} 17 \mathrm{H} 340$ & 270 \\
\hline 18 & 1-Nonadecene & 35.013 & 4.16 & $\mathrm{C} 19 \mathrm{H} 38$ & 266 \\
\hline 19 & Neophytadiene & 38.491 & 2.24 & $\mathrm{C} 20 \mathrm{H} 38$ & 278 \\
\hline
\end{tabular}

$[16,17]$. Hexadecanoic acid compound, nematicide methyl ester compound, insecticide, antibiotic, antioxidant, hypocholesterolemic activity [18]. Caryophyllene compound having anti-inflammatory activity [19]. Hexadecanoic acid phytochemical portion, methyl ester having anti-androgenic activity in Neolamarkia Cadamba leaf extract (Table 2). GCMS study of Martynia Annua Linn methanol extract seeds having hexadecanoic acid, methyl ester compound. Gundidza et al. [21] studied antibacterial, antifungal and antioxidant activity and found that, R. Minima essential oil has average antibacterial activity of all reported bacterial species except
Clostridium perfringens and Klebsiella pneomoniae [21]. According to Bhakshu and Raju [22], the essential oil of $R$. heynei leaves exhibited a broad spectrum of antimicrobial activity. The screening showed that Micrococcus luteus, Staphylococcus aureus and Pseudomonas aeruginosa were the highest inhibitory activity followed by Bacillus cereus, Candida tropicalis, C. albicans and Aspergillus niger were immune to the oil examined. In the case of R.minima mediated synthesis of gold nanoparticles, the alkyne group, acyl halide, secondary amine in alkaloids and alkyl halides such as iodine and bromine compounds may be involved in reducing gold chloride into 
Table 2: Activity of bioactive compound identified in the methanolic leaf extracts of R.minima

\begin{tabular}{lll}
\hline Sr No. & Name of compound & Activity \\
\hline 1 & 1-Heptadecene & Antibiotic [16] \\
2 & 8-Octadecanone & Antimicrobial [16] \\
3 & Hexadecanoic acid, & Nematicide, Insecticide, Antifungal, \\
& methyl ester & $\begin{array}{l}\text { Antibiotic, Flavor, Pesticide, Antioxidant, } \\
\text { Hypocholesterolemic, 5- Alpha reductase } \\
\text { inhibitor [17,18] }\end{array}$ \\
& & Anti-inflammatory activity [19] \\
\hline
\end{tabular}

Table 3: FTIR spectral wavenumber's values and functional groups obtained from the leaves powder of $R$. minima [20]

\begin{tabular}{lll}
\hline Sr No. & Wavenumbers & Functional groups \\
\hline 1 & 607.63 & Disulfides (S-S Stretch) \\
2 & 772.89 & Aliphatic Chlorocompounds (C-Cl Stretch) \\
3 & 1034.83 & Phosphate ions \\
4 & 1231.63 & Aromatic Ether, aryl-O Stretch \\
5 & 1524.95 & Arpomatic nitro Compounds \\
6 & 1687.00 & Open chain amino (-C = N-) \\
7 & 1733.11 & Ester \\
8 & 1781.39 & Open chain acid anhydried \\
9 & 2317.45 & Unknown \\
10 & 2364.47 & Unknown \\
11 & 2850.63 & Methylene (-H asym./sym-Stretch ) \\
12 & 2912.65 & Alkanes (CH) \\
13 & 3280.58 & Normal Polymeric OH Stretch \\
14 & 3557.44 & Internally bonded OH Stretch \\
15 & 3615.65 & Tertiary Alcohol, OH Stretch \\
16 & 3680.01 & OH -Stretch acidic \\
17 & 3740.40 & Unknown \\
18 & 3851.81 & Unknown \\
\hline
\end{tabular}

gold nanoparticles, and these compounds may also serve as reducing and capping agents $[23,24]$ Preliminary phytochemical screening of the R. minima aqueous leaf extract revealed the presence of alkaloids, flavonoids, tannins, terpenoids and glycosides [25].

\section{CONCLUSIONS}

In the current evaluation, a study of Gas Chromatogram-Mass spectrometry (GC-MS) has identified nineteen bioactive compounds from the methanolic leaf extract of R. minima. The presence of various bioactive compounds in R. minima has shown that the pharmaceutical significance. FTIR anlysis of R. minima leaves shows lipid, protein, phosphate ions, carboxylic acid, hydroxy compound, aliphatic bromo compound (Figure 2 and Table 3) [20]. Rhynchosia is an economically important genus that is distributed all over the world. Phytochemical investigations into many species of Rhynchosia have shown that the genus is limited to the abundance of C-glycosylflavonoids developing. The Rhynchosia's preliminary phytochemical screening revealed alkaloids, flavonoids, tannins, terpenoids, and glycosides. Wild legume Rhynchosia is a rich source of phytochemicals and nutrition and provides possibilities for advancement as a stand-by for cultivated species as a vegetable. The several species of Rhynchosia exhibit antioxidant, antimicrobial, anti-nutritional, antifungal, antidiabetic, antiinflammatory and anticancer activities that suggest they have a range of medicinal properties as well as exceptional nutritional potential.

\section{ACKNOWLEDGMENT}

The acknowledge the authorities of Department of Botany, Shivaji University, Kolhapur for extended support \& providing necessary lab facilities.

\section{REFERENCES}

1. Patil D A. Flora of Dhule and Nandurbar District (Maharashtra) Bishen singh Mahendra Pal singh Publishers and Distributors, Dehra Dun, India 2003

2. Kadhim $\mathrm{M} \mathrm{J}$, Ghaidaa $\mathrm{J} \mathrm{M}$ and Imad $\mathrm{H} \mathrm{H}$. In vitro Antibacterial, antifungal and phytochemical analysis of methanolic extract of fruit Cassia fistula. Oriental Journal of Chemistry. 2016: 32: 1329-1346.

3. Mohamed ZZ, Fasihuddin B A, Wel-S H, Shek L P. Gc-Ms analiysis of phytochemical constituents in leaf extract of Neolamarkia Cadamba (Rubiaceae) From Malaysia. International journal of Pharmacy and Pharmaceutical Sciences .2014: 6; 123-127.

4. Mali R G and Mahale N B. C-Glycosylflavones from Rhynchosia minima. Phytochemistry 1977: 16; 498.

5. Shah G L, Menon A R, Gopal G V. An account of the Ethanobotany of Saurashtra in Gujara state (India). Journal of Economic and Taxonomic Botany. 1981: 2; 173-182.

6. Sermakkani M And Thangapandian V. GC-MS analysis of Cassia italica leaf methanol extract. Asian Journal of Pharmaceutical and Clinical Research. 2012: 5; 90-94.

7. Ahmed W, Ahmed Z, Mali A. Stigmasteryl galactoside from Rhynchosia minima. Phytochemistry. 1992: 31; 4038-4039.

8. Ali A, Olabassar, Inas A Q, Mazahar F. GC-MS Analysis, HPTLC Fingerprint profile and DPPH free radical scavenging Assay of methanol extract of Martynia Annua Linn. seeds.2019:11:16-22.

9. Prasad K and Swamy N. Rhynchosia ravii (LeguminosaePapilionoideae), a new species from Andhra Pradesh, India. Phytotaxa 2014:175: 159-160.

10. Aluru Rammohan, Guda Mallikarjuna Reddy, Baki Vijaya Bhaskar Duvvuru Gunasekar ,Grigory V. Zyryanov Planta .2020:9:251

11. Harvey. A. L. Natural products in drug discovery. Drug discov Today. 2008: 13:894-901

12. Koehn. FE, Carter. GT. The evolving role of natural products in drug discovery. Nature Reviews Drug Discovery. 2005: 4:206-220.

13. Newman. DJ, Cragg. GM. Natural products as sources ofnew drugs over the 30 years from 1981 to 2010. Journal of Natural Products. 2012; 75:311-335.

14. González-Tejero MR, Casares-Porcel M, Sánchez-Rojas CP, RamiroGutiérrez JM, Molero-Mesa J, Pieroni A, Giusti ME, Censorii E, De Pasquale C, Della A, Paraskeva-Hadijchambi D. Medicinal plants in the Mediterranean area: synthesis of the results of the project Rubia. Journal of Ethnopharmacology. 2008: 116:341-357.

15. Butler MS. The role of natural product chemistry in drug discovery. Journal of Natural Products. 2004: 67:2141-2153.

16. Gunalan G, Krishnamurthy V. and (Late) Ariamuthu S. GC-MS and HPTLC fingerprinting of Bahunia varigata leaves for anticancer activity. World Journal of Pharmaceutical Research 2014:3:1313-1336.

17. John C. Interpretation of infrared spectra, a practical approach Encyclopedia Analytical Chemistry 2000

18. Selvarani K, Stella V, Bai G. GC-MS analysis of biologically active compounds in Cayratia pedata (lam) leaf and callus extracts. International Journal of Chemical Studies 2014:2:51-56

19. Mali R G, Hundiwale J C, Gavit R S, Patil D A and Patil K S: Herbal abortificients used in north Maharashtra .Natural product Radiance 2006:5:315-318.

20. FAO [Food and Agriculture Organization of the United Nations] Rhynchosis minima (L.) DC. 2006.

21. Gundidza M, Gweru N, Magwa M L, Ramalivhana N J, Humphrey G, Samie A and Mmbengwa V. Phytochemical composition and biological activities of essential oil of Rhynchosia minima (L) (DC) (Fabaceae). African Journal of Biotechnology 2009: 8:721-724.

22. L. Md. Bhakshu \& RR. Venkata Raju. Chemical composition and in 
vitro antimicrobial activity of essential oil of Rhynchosia heynei, an endemic medicinal plant from Eastern Ghats of India. Pharmaceutical Biology. 2009: 47(11); 1067-1070.

23. Ramasabbu M \& Veluchamy G. Comparing the possible mechanism in the reducing ability of leaves of two higher plants in the synthesis of gold nanoparticles. International Journal of Pharmaceutiacl Research and Bio-science. 2015: 4:102-115.
24. Ramasabbu M\& Veluchamy G. Comparing the possible mechanism in the reducing ability of leaves of two higher plants in the synthesis of gold nanoparticles. International Journal of Pharmaceutical Research and Bio-science. 2015: 4:102-115.

25. Mali R G \& Mahale N B. Evaluation of Rhynchosia minima (L) DC.leaves for Anthelmic activity. International Journal of Pharmacutical Sciences and Nanotechnology. 2008; 1:191-194. 